\title{
Milroy Disease: A Case Report
}

\author{
Gonçalo Gomes Pereira' ${ }^{1}$ Joana Moreira², Vaz de Macedoㅁ, Mário Santos ${ }^{2}$ \\ ${ }^{1}$ General Practice Departement, USF Sem Fronteiras, Santa Maria da Feira, Portugal \\ ${ }^{2}$ General Practice Departement, USF Covelo, Porto, Portugal \\ Email: joanamoreira95@gmail.com
}

Received 22 October 2015; accepted 10 November 2015; published 13 November 2015

Copyright (C) 2015 by authors and Scientific Research Publishing Inc.

This work is licensed under the Creative Commons Attribution International License (CC BY).

http://creativecommons.org/licenses/by/4.0/

c) (i) Open Access

\begin{abstract}
Hereditary lymphoedema type I is a congenital onset primary lymphoedema with autosomal dominant inheritance, which is characterized by the swelling of the lower body. In this article, the authors report a case of a 32-year-old woman with repeating episodes of swollen limbs. Imaging studies and genetic study were carried out and a Milroy's syndrome diagnosis was established. The patient started sintomatic treatment of the edema, with fitting stockings and descompressive massage, with symptomatic benefit.
\end{abstract}

Keywords

Milroy Disease, Lower Limbs Edema, FLT4 Gene, VEGFR-3

\section{Introduction}

Milroy disease (hereditary lymphoedema type I) is a congenital onset primary lymphoedema with autosomal dominant inheritance [1] [2], but, occasionally, it can develop later in life [1]. It is clinically and genetically heterogeneous [3] [4], showing both inter- and intrafamily variability in the severity of the edema [1] [4]. FLT4 gene mutation in the q35.3 locus is the most common mutation associated in Milroy's disease [5] [6]. The FLT4 gene provides instructions for producing a protein called vascular endothelial growth factor receptor 3 (VEGFR3), which regulates the development and maintenance of the lymphatic system. Mutations in the FLT4 gene interfere with the growth, movement, and survival of cells that line the lymphatic vessels (lymphatic endothelial cells). These mutations lead to the development of small or absent lymphatic vessels [2] [6] [7]. If lymph fluid is not properly transported, it builds up in the body’s tissues and causes lymphedema.

\section{Case Report}

A 32-year-old woman with repeating episodes of swollen limbs (Figure 1) and no other associated complaints presents herself in a consultation. The patient was questioned about her past medical history, family medical 
history, occurrence of cellulitis, venous problems as well as , age at onset of swelling, progression of the oedema over time and treatments of previous episodes. The patient reported a maternal aunt with lower limbs' edema as well as a personal history of varicose veins as well as three miscarriages. On examination, bilateral edema in the legs was present, with no associated inflammatory signs and no pain to palpation, the remaining examination was normal. Lower limbs venous ultrasonography was done, which proved normal. The patient was referred to a Vascular Surgery consultation. After lymphangiography showed lymphatic hypoplasia futher study was carried out with magnetic resonance imaging (MRI)-revealing edema and a lymphocele-as well as molecular genetic study which identified a mutation in the gene FTL4 chromosome 5q35-responsible for vascular endothelial growth factor receptor (VEGFR-3) expression establishing a Milroy's syndrome diagnosis. The patient then began sintomatic treatment of the edema, with fitting stockings and descompressive massage. After one month of treatment, the sweeling was reduced (Figure 2). Two years after the diagnosis, with correct managment of the disease and hipocoagulation, the patient got pregnant and had a full-term pregnancy.

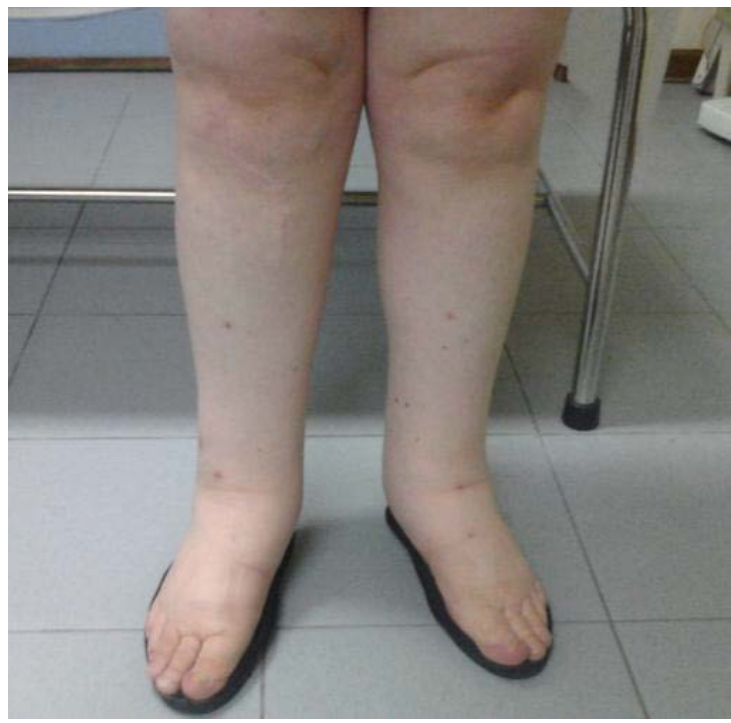

Figure 1. Patient with lower limbs edema due Milroy's disease.

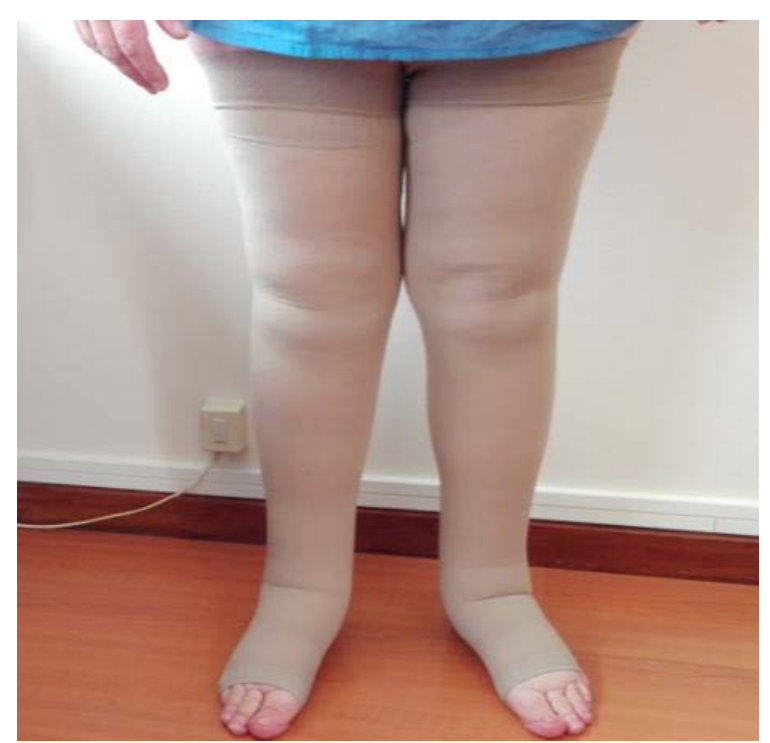

Figure 2. Patiente after treatment, with fitting stockings. 


\section{Conclusion}

Clinical onset at birth usually is a requirement for the clinical diagnosis of Milroy disease [6]. Nevertheless, there are exceptions with some mutations leading to swelling later in life, like in our patient, although, in some cases, early changes may be missed or as a result of variable expression or reduced penetrance [1] [8]. Treatment is aimed at reducing swelling and preventing infection. Complete decongestive therapy (CDT) is a form of treatment in which specialized manual techniques (manual lymph drainage) is combined with multilayered compression bandaging, meticulous skin care, exercise, and the use of well-fitted compression garments [5] [7] [8]. Decongestive and conditioning exercises are important components of CDT. Prevention of secondary complications is also importante [5] [8]. Frequency of cellulitis can be reduced through good skin hygiene, prompt treatment of infections with antibiotics, and prophylactic antibiotics for recurrent episodes [1]. Genetic counseling will benefit people with hereditary lymphedema and their families. It is very important adhere to lymphedema management recommendations to prevent progression the lymphedema and rehabilitation therapy may be even necessary in cases where extreme lymphedema impairs daily activities.

\section{References}

[1] Connell, F.C., Ostergaard, P., Carver, C., Brice, G., Williams, N., Mansour, S., Mortimer, P.S. and Jeffery, S. (2009) Analysis of the Coding Regions of VEGFR3 and VEGFC in Milroy Disease and Other Primary Lymphoedemas. Human Genetics, 124, 625-631. http://dx.doi.org/10.1007/s00439-008-0586-5

[2] Brouilhard, P., Boon, L. and Vikula, M. (2014) Genetics of Lymphatic Anomalies. The Journal of Clinical Investigation, 124, 898-904.

[3] Gordon, K., Schulte, D., Brice, G., Simpson, M.A., Roukens, M.G., van Impel, A., Connell, F., Kalidas, K., Jeffery, S., Mortimer, P.S., Mansour, S., Schulte-Merker, S. and Ostergaard, P. (2013) Mutation in Vascular Endothelial Growth Factor-C, a Ligand for Vascular Endothelial Growth Factor Receptor-3, Is Associated With Autosomal Dominant Milroy-Like Primary Lymphedema. Circulation Research, 112, 956-960. http://dx.doi.org/10.1161/CIRCRESAHA.113.300350

[4] Spiegel, R., Ghalamkarpour, A., Daniel-Spiegel, E., Vikkula, M. and Shalev, S. (2006) Wide Clinical Spectrum in a Family with Hereditary Lymphedema Type I Due to a Novel Missense Mutation in VEGFR3. Journal of Human Genetics, 51, 846-850. http://dx.doi.org/10.1007/s10038-006-0031-3

[5] Andrade, M. (2008) Linfangiogênese e genética dos linfedemas—Revisão da literatura. Jornal Vascular Brasileiro, 7 , 256-261. http://dx.doi.org/10.1590/S1677-54492008000300011

[6] Evans, A.L., Brice, G., Sotirova, V., et al. (1999) Mapping of Primary Congenital Lymphedema to the 5q35.3 Region. The American Journal of Human Genetics, 64, 547-555. http://dx.doi.org/10.1086/302248

[7] Mellor, R.H., Hubert, C.E., Stanton, A.W.B., et al. (2010) Lymphatic Dysfunction, Not Aplasia, Underlies Milroy Disease. Microcirculation, 17, 281-209.

[8] Brice, G., Child, A.H., Evans, A., Bell, R., Mansour, S., Burnand, K., Sarfarazi, M., Jeffery, S. and Mortimer, P. (2005) Milroy Disease and the VEGFR-3 Mutation Phenotype. Journal of Medical Genetics, 42, 98-102. http://dx.doi.org/10.1136/jmg.2004.024802 